Page 1 of 34

Title: Who knows what are school leavers and graduates doing? Comparing research programmes within Europe

Date of submission: 06/07/2013

Date of resubmission: 13/12/2013

\title{
Who knows what school leavers and graduates are doing? Comparing research programmes within Europe
}

\author{
Many current national and institutional education policies address the issue of \\ raising participation amongst young people and enhancing employability after \\ leaving school or university. What sort of information are these policies built on? \\ This paper compares national information systems from the last three decades \\ across Europe that gather information on school leavers' and graduates' pathways \\ after compulsory education. Using documentary data collected systematically the \\ paper describes the main focus, the research design and the sampling frame of the \\ school leavers' and graduates' information systems (SLGIS) arriving at several \\ different typologies. This paper gives an overall picture of what sort of research \\ is conducted within the area of school leaving and graduation and points out the \\ advantages and disadvantages of the different approaches. Beyond these, the \\ paper gives an indication of how the school leavers and graduates data is used \\ within the different European contexts and points towards the next steps of this \\ meta-research: case-studies on how the school leavers' and graduates' data is \\ applied at the national and the institutional level.
}

Keywords: school leaving and graduation; educational research methodology; European comparison; comparative education; school-to-work transitions

\section{Introduction}

Considerable resources are spent on school leavers' and graduates' information systems in numerous European countries, but it is not clear what happens to the results. In principle, SLGIS promise several benefits. First, they can help governments and researchers to explore the mechanisms of knowledge societies, and yield important and relevant information on the outcomes of education and learning. Second, educational institutions may require information on their former students' performance in the next educational stage or at their subsequent work place. Third, they can distribute 
Page 2 of 34

Title: Who knows what are school leavers and graduates doing? Comparing research programmes within Europe

Date of submission: 06/07/2013

Date of resubmission: $13 / 12 / 2013$

information about the necessary skills and competencies for the different careers, and prepare current students for the school to work transition (EU, 2009). Fourth, they may provide information which could be used to strengthen tuition and help the transition of students, particularly those faced by apparent barriers to further participation (Gorard et al., 2007). Through investigating how different European school leavers' and graduates' information systems are set up, this papers entangles the stories that they could tell us. The paper and it also identifies the main data gaps left in the strand of school leavers' and graduates' research.

\section{What data are collected by the European Union?}

There seem to be more and more questions arising within the field of education and its policy areas in relation to which the European Union has something to say. However, this was not always the case. As education in the forming years of the EU was seen as a national responsibility and the 'construction of the European Union [was] marked by perplexing silence around education policy' (Dale and Robertson, 2009, Lawn and Grek 2012: 13), the only issues that gained attention in the past concerned strong links to the economic agenda like that of vocational education and training, a part of the labour market and social policies (Beukel, 2001). In recent years especially the Education and Training 2010 work programme and the successive Strategic framework for education and training - ET 2020, drew attention to policy topics like lifelong learning, early school-leaving and tertiary attainment (EU, 2009, Council, 2001, Council, 2002). The role of the EU regarding these agendas is mainly enacted through 'soft governance' tools, the unobtrusive powers of best practices and the 'hidden politics of data and standards' (Lawn and Grek, 2012: 51). To achieve this, indicators 
Page 3 of 34

Title: Who knows what are school leavers and graduates doing? Comparing research programmes within Europe

Date of submission: 06/07/2013

Date of resubmission: 13/12/2013

and benchmarks are set for the educational policy fields along with the agreement on the ways of monitoring national and supra-national progress (Alexiadou et al., 2010, Lange and Alexiadou, 2007, EU, 2009).

To make monitoring possible, the EU gathers information on several policy topics. The project of informing Europe and the decision making of the Union started with the statistical team set up at the construction of the EU that lead to 'measuring' Europe and presenting a diverse set of data on the Eurostat website (Michelis and Chantraine, 2003). Beyond the statistical data-collection, the European Union is also involved in financing different cross-national research projects related to more specific research areas. Halász (2012) argues that the importance of research data gathered from the nation states is underpinned by two main reasons. First, the European, transnational level has to convince the national level about the significance of the proposed policy change and this can be achieved through providing a solid evidence-base. Second, the transnational decision makers are 'far away' from the national educational field and this creates information shortage that can be partly filled through commissioning research projects within education.

\section{What is known about school leaving and graduation?}

This paper looks at a specific policy area and whether the EU and the different nation-states of the EU have information about it. The policy area is school leaving and graduation and how this phenomenon is measured within the European context. Note that this paper does not detail the existence or the methodologies of research programmes on early school-leavers, or drop-outs, or NEETs. 
Page 4 of 34

Title: Who knows what are school leavers and graduates doing? Comparing research programmes within Europe

Date of submission: 06/07/2013

Date of resubmission: 13/12/2013

The immediate and longer term outcomes of education at the European level are only partly covered by the Eurostat, providing some indication of the outcomes of school leavers' and graduates'; this data derives from Labour Force Survey. However, there have been numerous attempts to gain a European picture of school leaving and graduation in the past decades 'either by organising a further data compilation in the various countries or by combining data that have been collected elsewhere' (Mainguet, 1999: 44). The majority of these cross-national comparative research projects were framed as researching 'school-to-work transitions'. The conventional view of transition from school to work defines it as the period between departing from compulsory education and arriving into a stable work position at the labour market (Müller and Gangl, 2003).

A few examples of cross-country analysis of school-to-work transitions are: the Comparative Analysis of Transitions from Education to Work in Europe (CATEWE) project running between 1997 and 2000; the Careers after Higher Education, a European Research Study (CHEERS) project running between 1998 and 2000; The Flexible Professional in the Knowledge Society New Demands on Higher Education (REFLEX) in Europe project running between 2004 and 2007 and the Higher Education as a Generator of Strategic Competences (HEGESCO) running between 2007 and 2004. These studies use a number of different resources, like cross-national surveys with a more general focus, cross-national transition surveys or occasionally, comparative qualitative studies on the one hand, and national transition research on the other (Raffe, 2008).

The comparison of transition-systems according to Raffe (2008: 292) suggests 'the path-dependency of countries and the failure of national transition patterns to 
Page 5 of 34

Title: Who knows what are school leavers and graduates doing? Comparing research programmes within Europe

Date of submission: 06/07/2013

Date of resubmission: 13/12/2013

converge', which challenges some of the theories of modernisation and globalisation.

Along the persistent divergence of transition-systems, there is diversity in the national information systems that measure school leaving and graduation or school-to-work transitions as well. There are numerous national school leavers' and graduates' information systems operating with distinct methodologies and time-frames making comparisons problematic and rarely allowing for capturing European mobility (Müller and Gangl, 2003).

In an international comparative account on how graduates' information is collected Gaebel et al. (2012: 16) suggest that 'the tracking of students and graduates has so far received little attention, at least at European level'. Their work concerns the methodology and how the data about current and former students is used within higher education in different European countries. The study entitled Tracking Learners' and Graduates' Progression Paths (TRACKIT) gathered information on tracking methodologies within and after university (Gaebel et al., 2012). Gaebel et al. (2012) distinguish between student and graduate tracking at the institutional, regional, national and international level through the distinct methodologies of conducting surveys and using administrative data.

This paper concerns a similar topic; it provides a meta-analysis of both the secondary and the tertiary levels as overarching, national level research programmes gathering information on school leavers and graduates. This paper, however, does not provide information on the tracking methodologies within the institutions. This paper provides an account of all school leavers' and graduates' information systems within Europe, and identifies their main focus points and what research design and methodology they use. Through outlining and describing these, this paper also takes a 
Page 6 of 34

Title: Who knows what are school leavers and graduates doing? Comparing research programmes within Europe

Date of submission: 06/07/2013

Date of resubmission: 13/12/2013

step towards encouraging an 'agreement on a 'best practice' template to facilitate the partial harmonisation of existing transition surveys' at the European level suggested by the CATEWE research team more than ten years ago (Smyth et al., 2001: i).

\section{What are the underlying ideas of school leavers' and graduates'}

\section{information systems?}

The ways information systems are set up and how their outcomes are used by the different stakeholders pre-suppose answers to the crucial question of 'what education is for'. Three possible understandings of what education is for, the sociological, the humanistic and the economic views are considered regarding the underpinning ideas of SLGIS. This research aims to understand how these stances inform the design of different school leavers' and graduates' information systems.

The sociological model considers education to be a common good that has a social purpose (Field, 2002, Ouane, 2009, Schuller, 2009). Therefore the focus of the sociological view of education is how the 'group' gaining education benefits or deteriorates the wider society. Education is thought of as a possible vehicle for social mobility, but is also often viewed as a vehicle to reproduce social inequalities and the acceptance of the status-quo (Macionis and Plummer, 2008). A sociological model of a

SLGIS would foreground the implications of education and training for social mobility and social stratification.

The second, humanistic model considers education as a means of achieving a fulfilled person through personal development. In a humanistic model the learningneeds of the individual person are in the focus. In this model the individual is in the centre as opposed to the previous approach and its focus on society. Such view of 
Page 7 of 34

Title: Who knows what are school leavers and graduates doing? Comparing research programmes within Europe

Date of submission: 06/07/2013

Date of resubmission: 13/12/2013

education concerns questions of the extent and process of personal fulfilment, identity formation and citizenship.

The third, economic view treats education as an investment that is similar to investing in physical capital (Psacharopoulos and Patrinos, 2004, Brown and Sessions, 2004). The core idea of human capital theory is that investment in education generates a stream of future benefits for the individual as higher earnings. The outcome for society is a more productive economy (Becker, 1993, Cohn, 1979). A human capital theory approach prompts questions around the returns to education, how the initial earnings and the earnings over a lifetime compare for the different educational levels and sectors (Psacharopoulos and Patrinos, 2004, Becker, 1993, Cohn, 1979, Mincer, 1974).

\section{Definition of the topic of this research}

The school leavers' and graduates' research programmes are referred to throughout as 'school leavers' and graduates' information systems' or SLGIS to distinguish them from 'this research' that this paper is based on.

The main criteria for a school leavers' and graduates' information systems to 'qualify' as a potential case in this research are set for this paper as follows. The aim of this research is to give a picture of the efficiency of national educational and training systems. Thus, the school leavers' and graduates' information systems examined in this paper collect and analyse leavers' and graduates' data at the national level and they account for more than one level of the educational and training system, covering both secondary and tertiary levels. As a further aim is to classify school leavers' and graduates' information systems that are systematic and account for changes within the 
Page 8 of 34

Title: Who knows what are school leavers and graduates doing? Comparing research programmes within Europe

Date of submission: 06/07/2013

Date of resubmission: 13/12/2013

educational and training system, they should collect data from more than one cohort of young people or the same cohort should be contacted several times throughout following them up.

The research excludes countries with school leavers' and graduates' research where the only scope is a certain region or a specific institution, since the observational unit, which 'refers to the unit used in data collection and data analysis to address the research questions' (Ragin, 1987: 9), is the nation state level.

\section{What do the school leavers' and graduates' information}

\section{systems measure?}

These information systems gaining information about leavers of schools and graduates of universities and their pathway after leaving the institution aim to conceptualise and measure what outcomes of education and training are realised. The hypothesis of this paper is that the underlying concept of these leavers' and graduates' information systems concerns the returns of education like the shorter and longer term earnings and outcomes, especially comparing different educational sectors, levels, and subject areas. This view on education seems to be built on human capital theory. This paper poses the question in relation to the focus and the methodology of the school leavers' and graduates' information systems: are they enabling the analysis of the 'rates of returns on such investment' as education and training (Psacharopoulos and Patrinos, 2004: 1, McMahon, 2004, Bradley and Nguyen, 2004, Becker, 1993, Cohn, 1979)? 
Title: Who knows what are school leavers and graduates doing? Comparing research programmes within Europe

Date of submission: 06/07/2013

Date of resubmission: 13/12/2013

\section{Research questions of this paper}

This paper is a descriptive account of the available school leavers' and graduates' information systems within Europe, asking the following research questions:

- In which European countries do school leavers' and graduates' information systems exist? Is it possible to observe any policy borrowing in relation to school leavers' and graduates' information systems methodologies?

- What is the focus of the observed school leavers' and graduates' information systems? Why do they exist?

- How are these school leavers' and graduates' information systems conducted in the different European countries with regards to the research design, the sampling and data collection methods as well as the time and space constraints of the research projects?

\section{Research methodology of this paper}

This new research uses an international comparative research frame analysing the similarities and differences between school leavers' and graduates' information systems that exist in Europe (Phillips and Schweisfurth, 2006). Using a comparative research frame can help the understanding of a particular educational system through broadening the horizon from the system level to a wider picture (Grant, 2000). This paper provides an overview of the first phase of this research, providing a snapshot of the 'current' versions of the SLGIS. This first phase has a cross-sectional design that helps to find variation among the groups or clusters of school leavers' and graduates' information systems without accounting for change over time (de Vaus, 2001). This research analyses the SLGIS within their national education and labour market systems. 
Page 10 of 34

Title: Who knows what are school leavers and graduates doing? Comparing research programmes within Europe

Date of submission: 06/07/2013

Date of resubmission: 13/12/2013

However, as this paper uses a fairly standardised approach, there is little space to account for the broader national characteristics.

This paper is based on systematic documentary analysis to gain a picture about school leavers' and graduates' information systems currently in place in European nation-states. All twenty-seven member states of the European Union are under scrutiny in the beginning of 2013 and additional nation-states that have special relations with the EU are drawn into the analysis, like Iceland, Norway, Liechtenstein and Switzerland. This research has a major drawback of language differences: despite the systematic search for school leavers' and graduates' information systems the researcher cannot be certain that all existing national information set were found.

The procedure of finding the relevant documents is built on multiple stages and it is an iterative process. The documents gathered are web-based official documents that provide some detail about the school leavers' and graduates' information system. As the SLGIS in the several national contexts take very different shapes in terms of their institutional setting, a number of steps are taken to find sufficient information on them. First, specific search-terms are entered into search-engines to map out national SLGIS. In a second step, the educational ministry websites are searched for references on school leavers' and graduates' data both in English and in the home-language. In a third step the search is extended to other websites, like the labour market ministries, educational research organisations, as well as national statistical organisations. In a fourth step to identify any SLGIS that is not conducted by the national governments, a systematic search is conducted through the Education Resources Information Center (ERIC) for academic articles on school leavers' and school-to-work transitions. To cross-check the available information gathered the TRACKIT study is used. 
Title: Who knows what are school leavers and graduates doing? Comparing research programmes within Europe

Date of submission: 06/07/2013

Date of resubmission: 13/12/2013

The documentary data gathered is coded and cross-tabulated along these variables. The key variables defined for the analysis are the focus, the research design, the methodology, the analysed population, the repetition, the age group covered, the time period and the region of the SLGIS.

\section{Description of school leavers' and graduates' information}

\section{systems in Europe}

The following sections analyse and compare several aspects of school leavers' and graduates' information systems. First, a detailed account is provided about the existence or absence of school leavers' and graduates' information systems in different regions of Europe. Second, the regional variation is described in terms of what educational levels are covered by the different school leavers' and graduates' information systems. Third, the main focus-points of the SLGIS are categorised into four types and a detailed example is provided for each of those categories. Fourth, the research design of the school leavers' and graduates' information systems is analysed along the population covered to point out the advantages and disadvantages of the different approaches. The fifth section is a short account of the time-frame of the school leavers' and graduates' information systems. Table 1 provides an overall picture, covering all the topics in these sections mentioned.

Table 1. School leavers' and graduates' information systems in Europe [Insert table here] 
Title: Who knows what are school leavers and graduates doing? Comparing research programmes within Europe

Date of submission: 06/07/2013

Date of resubmission: 13/12/2013

\section{Regions and countries with and without SLGIS}

This paper identifies similarities and differences within regions in terms of research aims and methods of the school leavers' and graduates' information systems. Evidence of policy borrowing between countries in terms of SLGIS methodologies is apparent in the UK and Ireland context where the former joint English and Welsh survey is originally based on the Scottish experiences (Howieson and Croxford, 2008) as well as the between the Nordic countries, where using registry-data to compile national information sets is a common practice (Myrskylä, 2001, UnitedNations, 2007).

In terms of regional differences the majority of the countries in Northern and Western Europe have school leavers' and graduates' information systems; there are fewer programmes found in Southern Europe, as suggested in Table 2. It is mainly the Central and Eastern European countries that do not conduct systematic school leavers' and graduates' information systems covering more than one level of the education system.

Table 2. School leavers' and graduates' information systems in different regions [Insert table here]

The variance within Europe could yield a number of explanations. The differences between the regions could be attributed to the economic situation, where the countries with higher GDP spend more on educational research, as for instance gathering information on school leaving and graduation. However, some of the SLGIS were initiated in times of economic hardship mainly as an aid for government to plan policies tackling youth unemployment. A further explanation could be policy-borrowing 
Page 13 of 34

Title: Who knows what are school leavers and graduates doing? Comparing research programmes within Europe

Date of submission: 06/07/2013

Date of resubmission: 13/12/2013

within European Union in respect starting SLGIS. As suggested earlier, actual SLGIS methods borrowing can be found only in close-knit smaller regions of Europe, rather than within the whole supra-national area. The most plausible explanation seems to be related to the history of Europe, to the existence of communism as opposed to marketeconomy. In the areas where the communist ideology dictated a planned economy, there was no need to measure school leaving and graduation: everyone was supposed to comply with the labour market planning and take 'their place'. In the market-economy the role of the state is profoundly different. The state provides the structures and the market decides on the 'value' of school leavers' and graduates' from different institutions. This latter approach might raise the need to measure this 'value' and thus the need for information gathered through SLGIS (Standing, 1997).

\section{Levels of the education system in the SLGIS}

This section lists the actual school leavers' and graduates' information systems that are subject to this research and categorises them according to what level of the educational system they gather data on. There are three main approaches to conducting school leavers' and graduates' information systems at the different levels of the educational system. The first two columns of Table 1 containing the titles of the school leavers' and graduates' information systems give an overview of what level they collect data at. Several countries conduct separate school leavers' and graduates' information systems for their secondary level school leavers and a different project for the higher education graduates; these are Denmark, Northern-Ireland, Norway, the Republic of Ireland and Spain. A second type is countries using a holistic, overall approach to gain school leavers' and graduates' data (Austria, Belgium, the Netherlands and Sweden). A 
Page 14 of 34

Title: Who knows what are school leavers and graduates doing? Comparing research programmes within Europe

Date of submission: 06/07/2013

Date of resubmission: 13/12/2013

third category is those countries that have a holistic, overall school leavers' and graduates' information system and in addition to that they conduct regular data collections within higher education at the level of institutions. These countries are: England, Finland, France, Germany, Italy, Scotland and Switzerland.

Looking at the regional differences, we can see that with the exception of Denmark, the Nordic countries gather data through overall, comprehensive school leavers' and graduates' information systems. The countries of continental Europe all have holistic projects on the whole educational system and additionally, some conduct additional research projects on their higher education graduates. Whereas Ireland and Northern-Ireland have separate school leavers' and graduates' information systems for their secondary school leavers' and their graduates, England, Scotland and Wales have a graduate survey in addition to a holistic research project.

These differences matter in terms of what picture the school leavers' and graduates' information systems depict of a national educational system. Whereas the first approach does not allow for a comparison of secondary and tertiary outcomes, a country that has a holistic approach gains comparable data within and between the different educational levels. Comparability within and between the different levels and sectors of the system allows room for calculating the returns of education through applying a cost-benefit analysis, as the economists of the human capital theory set it out (Psacharopoulos and Patrinos, 2004, Becker, 1993, Cohn, 1979). The difference between system-level school leavers' and graduates' information and data collected at the institutional level pose two different questions. One is the attention of the central government: what levels and which sectors are 'important' enough to conduct school leavers' and graduates' information systems on? The second question concerns 
Page 15 of 34

Title: Who knows what are school leavers and graduates doing? Comparing research programmes within Europe

Date of submission: 06/07/2013

Date of resubmission: 13/12/2013

'responsibility': if the data depicts a system level picture, national policy-making could be seen responsible; if it evaluates a sector at the institutional level, schools and universities could be held accountable for the leavers' and graduates' results.

\section{The main focus of SLGIS}

The stated focus of the school leavers' and graduates' information systems is analysed in this paper on the basis of their description in the research reports and on the main websites of these data collections. This paper does not compare the questions included in the research instruments used in the school leavers' and graduates' information systems. Also, this paper does not analyse the intention behind setting up these school leavers' and graduates' information systems, nor the way they are used by different stakeholders.

Four main ideal-types of the school leavers' and graduates' information systems are identified with regards to their stated focus: they are either (i) examining the transition process from school-to-school or school-to-work, or (ii) analysing young people's life span more generally, (iii) or collecting data on the initial destinations of leavers' and graduates', or (iv) gathering information on the experiences of the first job and the training they had. These categories, however, are permeable; school leavers' and graduates' information systems in some cases set out to give answers to more of these interrelated questions. A category was chosen that sums up best the research foci; the categorisation is detailed in Table 1 in the 'Focus' column.

The most established and older school leavers' and graduates' information systems dating from the 1970-1980s tend to examine the transition period from school to further education or to work, or the first destinations of leavers'. School leavers' and 
Title: Who knows what are school leavers and graduates doing? Comparing research programmes within Europe

Date of submission: 06/07/2013

Date of resubmission: 13/12/2013

graduates' information systems that were started in the 1990s were mainly concerned either with the transitions process, or the first experiences of leavers' and their initial career pathway. The latest school leavers' and graduates' information systems started after 2000 have diverse foci; many deal with the transition process and there are a number of research programmes in the other three categories as well. After this summary, this section details what the different research projects set out as their focus and illustrates the different types with one example.

The first type of school leavers' and graduates' information systems is dealing with the transition process from school-to-school or school-to-work. It aims to gather data on the relatively short period of being between schools and the labour market, with an emphasis on how former students assess their progress at a higher education institution or in further training or how they are able to find a workplace. As the already mentioned CATEWE international research project set 'transition' in its conceptual framework:

(...) the concept of transition is seen as referring to a sequence of statuses or positions achieved over a period of time from a point in full-time education (...) to a point some years later when the majority of such system leavers have achieved a "stable" adult status. (Hannan F. et al., 1999: 18)

These research programmes are mostly conducted in Continental Europe; Finland and Sweden represents the Nordic countries and such research programmes are in place in Scotland and in Ireland. 
Page 17 of 34

Title: Who knows what are school leavers and graduates doing? Comparing research programmes within Europe

Date of submission: 06/07/2013

Date of resubmission: 13/12/2013

The French study Génération is carried out by the Centre d'études et de recherches sur les qualifications (Céreq). The study is following a number of cohorts of young people for seven years and is described on the Céreq website (2010) as 'an appropriate statistical tool for monitoring transition-to-work paths and occupational trajectories'. The Génération research gathers data on leavers from schools as well as universities; thus the main criteria to be in the sample is to have left in the given year, not started schools or university again within one year, and not being older than 35 years (Céreq, 2011).

The second main type of school leavers' and graduates' information systems analyse the lifespan of young people more generally, concentrating on broader issues beyond the educational experiences and the young person's progress to further and higher education and the labour market. These sorts of information programmes are conducted in England (two projects) and in Germany.

The English and Welsh Youth Cohort Study (YCS) was designed 'to monitor the behaviour and decisions of representative samples of young people aged sixteen upwards' (ESDS, 2008). As the Longitudinal Study of Young People in England (LSYPE) was building on the YCS, it has a similar focus according to the website:

The main role of the study is to identify, and enable analysis and understanding of, the key factors affecting young people's progress in transition from the later years of compulsory education, through any subsequent education or training, to entry into the labour market or other outcomes. (ESDS, 2011) 
Page 18 of 34

Title: Who knows what are school leavers and graduates doing? Comparing research programmes within Europe

Date of submission: 06/07/2013

Date of resubmission: 13/12/2013

Although the data description of the LSYPE says it is gathering data on 'the transitions young people make from secondary and tertiary education or training to economic roles in early adulthood' (ESDS, 2012), as a review of this dataset states, it covered several wider issues of young people's lives:

[The] past Waves of the first LSYPE cohort have focused on the educational experiences of young people, but other issues have also been covered including their views on local areas, community cohesion, participation in social activities, participation in risky behaviours, crime or anti-social behaviours, health, and their aspirations for the future. (Collingwood et al., 2010: 20)

The third type of school leavers' and graduates' information systems collect data on the destinations of the leavers' or graduates' when they leave compulsory schooling or a tertiary level institution. This type of data collection sets out to collect information on the immediate destinations, very soon after leaving school or university. These school leavers' and graduates' information systems mainly gather data on the current status of the former student, their first work experiences and, most importantly, their view on their previous education. These data collections can be found in the United Kingdom and Ireland and such projects are conducted in Finland as well.

The main Finnish dataset complied by Statistics Finland using administrative data deals with the transition from schools and universities to higher education or the labour market (Statistics Finland, 2011, Statistics Finland, 2012).The combination of administrative data, this dataset does not provide in-depth information on the labour market outcomes. There are additional higher education graduates' surveys by the institutions. One of these projects is referred to as the Aarresaari Network's (guidance 
Page 19 of 34

Title: Who knows what are school leavers and graduates doing? Comparing research programmes within Europe

Date of submission: 06/07/2013

Date of resubmission: 13/12/2013

network at university level) 'first destinations' or 'placement follow-up' (Saino, 2010).

It gathers data on the initial labour market outcomes, the graduate's opinion on their recent studies and how the university prepared them to meet the needs of the labour market.

The fourth type of school leavers' and graduates' information systems collect data on young people's first impressions of being on the labour market and their experiences after entering it. These projects - as opposed to the first destinations and the transitions process - set out to gather information on the longer term career outcomes of leavers' and graduates' and their experiences at the labour market. The information collected on their experiences within the educational system plays a role only in relation to how applicable their skills and knowledge gained from education are in their labour market positions. The school leavers' and graduates' information systems within this category are from Continental Europe, from Finland and from the Southern-European countries.

The Spanish studies on the entrance to the labour market of young people aim to give an idea about how young people cope with the first few years of entering the labour market (García-Montalvo and María Peiró, 2011). The school leavers' and graduates' information system that deals specifically with higher education gathers data about the integration of graduates to the labour market (ANECA, 2009).

This section categorised the school leavers' and graduates' information systems according to their focus: what is the main information they aim to collect? Although some of the school leavers' and graduates' information systems might fit more categories, it is possible to identify one for each that suits them the best. 
Title: Who knows what are school leavers and graduates doing? Comparing research programmes within Europe

The different foci that the SLGIS could be set up with can tell fairly different stories regarding education. The typology above relates to differences in the timing of the SLGIS as well, detailed in the next sub-section. Whereas the information systems researching the life of young people and the first impressions of the labour market provide a longer term picture, the transitions research tends to refer to the first few years after school leaving and graduation. The destinations SLGIS tend to have the shortest time-frames, viewing the immediate outcomes.

The types of outcomes these information systems aim to cover do not show a great diversity. The SLGIS focusing on the immediate destinations, the transition from school-to-work and the first impressions of the labour market are all strongly related to the economic outcomes of schools and universities. As opposed to this, the information systems taking a broader view on a young person's life tend to have a stronger emphasis on the background data of former students. These suggest that the human capital view of school leaving and graduation might be more prevalent than the humanistic or the sociological view.

The school leavers' and graduates' information systems having diverse foci allow different perspectives on analysing the returns of education. The analysis of the lifespan more broadly allows claims on the longer-term outcomes, leavers' and graduates' information on the transition process or the first experiences at the labour market allow for a shorter time-frame and a more fragmented picture, whereas the first destinations programmes allow little room to draw conclusions on the 'returns' of education. One of these 'types' however, seems to be especially important in relation to human capital theory according to Bradley and Nguyen (2004): 
Title: Who knows what are school leavers and graduates doing? Comparing research programmes within Europe

Human capital theory is the most widely adopted framework for investigating the school-to-work transition. This is because the transition from school is often conceptualized as an investment decision to be made by young people, although there clearly is an element of consumption in the decision to go to college.' (Bradley and Nguyen, 2004: 486)

\section{How are these SLGIS set up?}

This section on methodological characteristics explores and describes the research design, the data collection methods and the sampling strategies of the information systems and the time period, the repetition, and the age group covered. The school leavers' and graduates' information systems analysed in this paper have either a longitudinal design, collecting data from one or more cohorts throughout a longer period of time; or they use a cross-sectional design to reach a cohort once, repeated with a subsequent cohort every year, or every few years. With regards to the population covered, two main types of school leavers' and graduates' information systems are identified; they are either built on a sample or on a census. Those school leavers' and graduates' information systems that gather information from a part of the cohort of leavers or graduates are based on a sample; they collect the information through survey questionnaires.

Along the methodology aspects listed in columns 'Research Design And Population' of Table 1 a typology of four can be identified to classify the SLGIS: 
Title: Who knows what are school leavers and graduates doing? Comparing research programmes within Europe

Date of submission: 06/07/2013

Date of resubmission: 13/12/2013

- Longitudinal designs based on sample survey: Belgium, England and

Wales, England, France (1), France (2), Germany (1), Germany (2),

Scotland (1), Scotland (3), Switzerland (1), Switzerland (2);

- Longitudinal designs based on census: Austria, Denmark (1), Denmark (2), Finland (1), Scotland (2);

- Cross-sectional designs based on a sample survey: Finland (2), Finland (3), Italy (1), Italy (2), Netherlands, Republic of Ireland (1), Republic of Ireland (2), Spain (1), Spain (2), Sweden (1), Sweden (2);

- Cross-sectional designs based on census: United Kingdom, NorthernIreland, Sweden (3), Wales.

The most 'popular' methodologies are those being built on a longitudinal or a cross-sectional sample design, the least information programmes can be found in categories relating to census-type approaches. School leavers' and graduates' information systems that are based on a census usually collect less detailed information about the individuals' circumstances, either due to the methodology of linked administrative data or to reduce respondent burden (Ruspini, 2002). SLGIS that gather data once or multiple times directly from a sample population usually provide a broader range of information about several topics relating to leaving or graduating.

This section takes an example of each type to indicate how school leavers' and graduates' data collections are set up.

There are eleven different school leavers' and graduates' information systems that take a longitudinal view on school leaving and they use samples of different cohorts 
Page 23 of 34

Title: Who knows what are school leavers and graduates doing? Comparing research programmes within Europe

Date of submission: 06/07/2013

Date of resubmission: 13/12/2013

to do so. The Belgian, the English and the Swiss research projects are built on one cohort of young people, all the others started more than one cohort to investigate school leaving and graduation.

The German study entitled National Educational Panel Study (NEPS) aims to analyse 'how education is acquired, to see how it impacts on individual biographies, and to describe and analyze the major educational processes and trajectories across the life span'; to achieve a 'successful individual and social life' (von Maurice et al., 2011: 2). The research project is built on a panel of multiple cohorts covering different age groups; the stages of sampling signify different phases of the school pathway and the labour market career from early childhood to adult education. In 2010 five cohorts are started; '[s]ample selection is oriented toward transitions both within the education system and between the education system and the labor market' (UniBamberg, 2010b: 20).

The total number of the population to be sampled is 60,000 ; they will be followed for ten years. The cohorts sampled in 2010 examine transitions 1) from kindergarten to elementary-school and then to lower-secondary; 2) from lowersecondary to upper-secondary and then to further or higher education with approximately 6000 respondents; 3) from upper-secondary to further or higher education and then to the job market with an aim to contact 14000 young people 4) from further or higher education to the labour market with approximately 31000 respondents (UniBamberg, 2010a). 'An exception is the fifth starting cohort recruited to study adult education', as it does not necessarily deal with transitions (UniBamberg, 2010b: 20, von Maurice et al., 2011). The research description does not detail attrition for the majority of the cohorts but it adds details of drop-out of the sample and the ratio 
Title: Who knows what are school leavers and graduates doing? Comparing research programmes within Europe

Date of submission: 06/07/2013

Date of resubmission: 13/12/2013

of boosting it for the 'adult' cohort (UniBamberg, 2010a). The research is built on questionnaire data combining personal and self-interviewing using paper questionnaires and computer assisted interviewing methods (UniBamberg, 2010a).

There are five school leavers' and graduates' information systems that use $a$ longitudinal design to acquire data on all, or virtually all young people of a given leavers' or graduates' cohort. Note, that in Scotland the data collection system entitled Destinations of Leavers from Scottish Schools and Follow up Survey of Leavers From Scottish Schools show leavers' information three months after leaving compulsory schooling and once more nine months after (ScotStat, 2009). The main issue with this research design is that according to some of the literature two measures are not sufficient to make inferences on change over time, because it is not possible to determine the direction of change from two snapshots (Ployhart and Vandenberg, 2010).

The Danish data collection on school leavers and graduates entitled Fra uddannelse til arbejdsmarked (From education to labour market) and Nyuddannedes beskaftigelse (Graduate Employment) respectively combine data using statistical registers, like student, employment and population registers, as well as taxation and pension registers (Statistics Denmark, 2012, Jensen, 2012). Acquiring a longitudinal perspective is possible through using 'flow statistics' where 'data on the same individual is chained together for consecutive time periods' (UnitedNations, 2007: 33). Thus the main information presented about the school leavers and graduates in these two separate accounts is the sort of activity they have a given period after leaving. Statistics Denmark provides information on the school leavers from general education a year after they have finished; however, the statistical database of the website makes it 
Page 25 of 34

Title: Who knows what are school leavers and graduates doing? Comparing research programmes within Europe

Date of submission: 06/07/2013

Date of resubmission: 13/12/2013

possible to look at the information over time as well (Statistics Denmark, 2012). The

Agency for Universities and Internationalisation that provides the data about graduates

of universities, gains them from Statistics Denmark as well. The key information is

whether former students are employed 4-19 months after graduation. The website

provides data on areas of studies and provides a comparison of cross-sectional accounts, and also analyses how the rate of unemployment changed in the first 4 to 19 months after graduation (Jensen, 2012).

The third category of school leavers' and graduates' information systems is built on multiple cohorts of cross-sectional accounts based on sample surveys; eleven research projects fall into this group.

The Italian National Institute of Statistics (ISTAT) conducts two research projects that are combined into a national level 'education-to-work transition' information. The research programme entitled L'Indagine sui percorsi di studio e di lavoro dei diplomati delle scuole secondarie di secondo grado (Survey on the educational and work experiences of upper secondary school leavers) gathers data on the upper-secondary leavers, the other titled Graduate Survey on graduates. The respondents in this school leavers' and graduates' information system are asked about their educational experiences as well as their labour market experiences, their job status and circumstances and their social background.

Both of these research projects are based on samples of leavers or graduates, contacting them three years after they have left the institution. These research programmes started in 1998; new cohorts are contacted every three years (ISTAT, 2011, ISTAT, 2012b). Data is collected through computer assisted telephone interviewing for 
Title: Who knows what are school leavers and graduates doing? Comparing research programmes within Europe

Date of submission: 06/07/2013

Date of resubmission: 13/12/2013

both research programmes. As for the samples, at the upper-secondary level an approximately $10 \%$ sample of the population was aimed to be contacted in 2007 , the response rate was around 65\%; for the university level the sample aimed was around $20 \%$ of the population, the final response rate was around 70\% (ISTAT, 2011, ISTAT, 2012a).

The fourth category of school leavers' and graduates' information systems are based on cross-sectional designs using data on all leavers - four research projects gather data this way.

One of these research projects is the United Kingdom-wide Destinations of Leavers from Higher Education (DLHE); the DLHE is built on asking all undergraduate full-time home students six months after graduation about their initial labour market outcomes through a questionnaire. The DLHE and its previous formats have been around in the UK since 1994/1995. The DLHE is built on offline and online questionnaires and telephone interviewing. All institutions having higher education provision across the United Kingdom have to achieve a very high, $80 \%$ response rate (HESA, 2007). For part-time students, international and EU-students the prescribed response rate is lower. As data is collected from the vast majority of graduates, due to time and financial constraints the questionnaire is relatively short and mainly contains information about the present activity of the graduate. Due to the DLHE being conducted by the institutions according to the guidelines of the Higher Education Statistics Agency (HESA), the national dataset makes it possible to compare institutions; the DLHE features in the university rankings as well (HESA, 2007). 
Page 27 of 34

Title: Who knows what are school leavers and graduates doing? Comparing research programmes within Europe

Date of submission: 06/07/2013

Date of resubmission: 13/12/2013

Considering the different categories of school leavers' and graduates'

information systems listed in this section in relation to literature on research design and sampling it is possible to outline the advantages and disadvantages of the different methodologies. Longitudinal designs can enable some causal inferences and analyse change at the individual level, whereas the cross-sectional designs allows aggregate, system level claims and do not show the 'developmental patterns' (Ruspini, 2000, Ruspini, 2002, Gorard, 2013). Longitudinal designs are costly and the time-lag have to be considered; cross-sectional designs give results more quickly and they are more costeffective as well (de Vaus, 2001, Hakim, 2000, Howieson and Croxford, 2008, Bryman, 2008, Newby, 2010).

In terms of the population contacted, a sample survey using questionnaires can gather information about the attitudes and the perceptions of former students and graduates, and their views on their past and plans for the future. A census most generally on registry data or very short questionnaires leaves little space for this sort of information. A sample, gathering data on a fraction of the cohort of young people does not allow institutional or individual level claims, whereas the census supports any level of sub-group comparison (Howieson and Croxford, 2008, Bryman, 2008, Smith, 2008, Myrskylä, 2001, Gaebel et al., 2012).

The optimal research design and sampling frame of the school leavers' and graduates' information systems depends on the main aims set out and the processes they are applied in. A research programme that is used in the audit and evaluation process of educational institutions should collect data on virtually every former student or graduate. A data collection that feeds back to the institution the perception of how useful the former education was should use a questionnaire to reach a part of the cohort. 
Title: Who knows what are school leavers and graduates doing? Comparing research programmes within Europe

Date of submission: 06/07/2013

Date of resubmission: 13/12/2013

An information system serving national policy planning should make causal claims possible through a longitudinal design; a data collection that is used in career-guidance has to provide longer term up-to-date information on transitions from school-to-work made possible. In terms of permitting the analysis of returns of education and training, comparability between the different levels and sectors of the educational system over a longer period of time is desirable, thus longitudinal research programmes are more suited (Cohn, 1979).

\section{'Time' covered by the SLGIS}

Although one of the criteria for the school leavers' and graduates' information systems analysed in this paper is that they should be systematic, this section shows how volatile they are: the repetition, the number of contacts as well as the age group covered is subject to change within many information systems.

As columns 'Starting year And Repetition' and the 'Repetition, Age group/Time after leaving' of Table 1 show, the majority of the analysed school leavers' and graduates' information systems are built on multiple samples of cohorts. Only a few of them deal with data from a single cohort, like the Swiss Transitions from Education to Employment (TREE) project or the English Longitudinal Study of Young People in England (LSYPE) (Bergman et al., 2010, ESDS, 2011). The majority of the crosssectional information systems are built on annual or biannual samples, whereas the longitudinal sample surveys have bigger gaps between the subsequent cohorts. This latter phenomenon could be due to the costs associated with longitudinal projects compared to cross-sectional accounts (Howieson and Croxford, 2008, Collingwood et al., 2010). In relation to the age group and for how long young people are followed, the 
Title: Who knows what are school leavers and graduates doing? Comparing research programmes within Europe

Date of submission: 06/07/2013

Date of resubmission: 13/12/2013

majority of the information systems analysed in this paper deal with the first 1-3 years of school leaving and graduation; some longitudinal projects, however, follow the respondents up to five-ten years after leaving the education system. As the Austrian, Finnish and Danish examples indicate, through the combination of registry data it possible to follow-up multiple cohorts for a very long time-period as well.

\section{Concluding remarks and further steps}

This paper gives an extensive account of the main features of the school leavers' and graduates' information systems in place within European nation-states. It points out a number of interesting similarities in relation to the focus as well as the methodology of the existing school leavers' and graduates' information systems. Due to the differences in the main focus and the research design of the existing information systems, they seem to allow little room for comparison across Europe. However, this paper might be a good starting point to take steps towards a common European school leavers' and graduates' account.

In terms of the underlying concept of the school leavers' and graduates' information systems human capital theory seems to be a possible model. This paper indicates the extent to which the school leavers' and graduates' information systems regarding their focus and methodology permit such analysis. This paper does not detail the concerns of applying this concept. The most crucial problem of the human capital analysis is suggested by Cohn (1979) regarding what data tends to be used:

\footnotetext{
'This approach [human capital theory] is based upon the premise that education results in direct, measureable returns to the individual and society. Although
} 
Page 30 of 34

Title: Who knows what are school leavers and graduates doing? Comparing research programmes within Europe

Date of submission: 06/07/2013

Date of resubmission: 13/12/2013

returns to individuals should be measured according to satisfaction derived now and in the future, data and conceptual problems have forced researchers to define returns in terms of income and earnings alone.' (Cohn, 1979: 38)

Cohn (1979) suggests that, in principle, the human capital 'rate of return' to education includes non-monetary (e.g. sense of self-esteem and cultural awareness) as well as monetary benefits. In fact anything that education adds to an individual's satisfaction should be included. However, in practice, rates of return are usually calculated only through earnings,

\section{Although returns to individuals should be measured according to satisfaction derived now and in the future, data and conceptual problems have forced researchers to define returns in terms of income and earnings alone. (Cohn,} 1979: 38)

A next step of this research is to consider what other concepts can underpin the different national school leavers' and graduates' information systems. Several further theoretical perspectives are used for instance within the school-to-work transition research (Raffe, 2008). To gain an understanding what school leavers' and graduates' information systems use, a deeper analysis is performed on selected cases.

As suggested in the introduction of this paper, there has been one comparative account so far related to the methodology of student and graduate information systems. The TRACKIT project details the methodologies of the different student and graduate tracking projects and providing an overview of which countries and regions have them 
Page 31 of 34

Title: Who knows what are school leavers and graduates doing? Comparing research programmes within Europe

Date of submission: 06/07/2013

Date of resubmission: 13/12/2013

in place. It also provides a discussion of what the different data-collections on students and graduates of higher education are used for. For instance, in relation to the national level graduate tracking the study suggests that it can be used for policy planning, quality assurance and sometimes allocation of funding. In relation to the institutional level they list general management activities, quality assurance, changing study programmes, resource allocation, promotional activities, counselling, gaining funding and fulfilling accreditation requirements (Gaebel et al., 2012). Then they assess what type of graduate tracking system suits these activities more.

The TRACKIT study points out the next important question for this research as well. Following on from this meta-analysis the next stages analyse how the school leavers' and graduates' information is applied in the different national contexts: what is beyond the stated focus? The methodology used in this paper allows some room to explore what the school leavers' and graduates' information systems focus on, while it gives little information about how different stakeholders might be using the data. The next stage of this research is based on case-studies to gain a better understanding of some of the national contexts in terms of how the policy, the institutional and the citizens' level have information about school leaving and graduation. The further aim of this research is to find out how the school leavers' and graduates' information systems are disseminated and used by the different actors, like policy makers, institutional leaders, career guidance experts, researchers within and outside academia, and the general public. This research in the next phase explores whether and how the characteristics of the described school leavers' and graduates' information systems are meaningful to their national contexts, and whose data needs are satisfied through these data collections. 
Page 32 of 34

Title: Who knows what are school leavers and graduates doing? Comparing research programmes within Europe

Date of submission: 06/07/2013

Date of resubmission: $13 / 12 / 2013$

\section{Reference}

ALEXIADOU, N., FINK-HAFNER, D. \& LANGE, B. 2010. Education Policy Convergence through the Open Method of Coordination: Theoretical Reflections and Implementation in "Old" and "New" National Contexts. European Educational Research Journal, 9, 345-358.

ANECA. 2009. Los procesos de inserción laboral de los titulados universitarios en España Factores de facilitación y de obstaculización [Online]. Madrid: Agencia Nacional de Evaluación de la Calidad y Acreditación. Available: http://www.aneca.es/Documentos-y-publicaciones/Otros-documentos-deinteres/Insercion-laboral/Los-procesos-de-insercion-laboral-de-los-tituladosuniversitarios-en-Espana [Accessed].

APM. 2012. About APM: University Graduates and Labor Market (APM) [Online].

Bucharest: Romanian Tracer Study. Available: http://www.absolventuniv.ro/772/section.aspx/431 [Accessed 15/01/2013].

ARNESEN, C. Å., STØREN, L. A. \& WIERS-JENSSEN, J. 2012. Arbeidsmarkedssituasjon og tilfredshet med utdanningen blant ulike grupper av nyutdannede [Online]. Oslo: Nordisk institutt for studier av innovasjon, forskning og utdanning. Available: http://www.nifu.no/Norway/Publications/2012/Rapp\%2039\%202012\%20for\%2 OWEB.pdf [Accessed 15/01/2013].

BECKER, G. S. 1993. Human Capital. A theoretical and Empirical Analysis with Special Reference to Education, Chicago and London, The University of Chicago Press.

BERGMAN, M., HUPKA-BRUNNER, S., MEYER, T. \& STALDER E., B. 2010. Transitions from Education to Employment - TREE PProject Documentation 2000-2007 [Online]. Basel: Institut für Soziologie der Universität Basel. Available: http://tree.unibas.ch/index.php?eID=tx_nawsecuredl\&u=0\&file=fileadmin/tree/r edaktion/docs/TREE_2010_Project_documentation_2000-

2007_version_2010_English.pdf\&t=1319728635\&hash=1 aa94de693d3ffdf79a3 e12b72a804da [Accessed 26/10/2011].

BEUKEL, E. 2001. Educational Policy: institutionalization and multi level governance. In: ANDERSEN, S. S. \& ELIASSEN, K. A. (eds.) Making Policy in Europe. London: Sage.

BFS. 2011. Surveys, Sources - Graduate Survey [Online]. Neuchâtel Federal Statistical Office. Available:

http://www.bfs.admin.ch/bfs/portal/en/index/infothek/erhebungen_quellen/blan k/blank/bha/01.html [Accessed 25/09/2013].

BRADLEY, S. \& NGUYEN, A. N. 2004. The school-to-work transition. In: JOHNES, G. \& JOHNES, G. (eds.) International Handbook on the Economics of Education. Cheltenham: Edward Elgar.

BROWN, S. \& SESSIONS, J. G. 2004. Signalling and screening In: JOHNES, G. \& JOHNES, G. (eds.) International Handbook on the Economics of Education. Cheltenham: Edward Elgar.

BRYMAN, A. 2008. Social Research Methdos, Oxford, Oxford University Press.

BYRNE, D., MCCOY, S. \& WATSON, D. 2008. School Leavers' Survey Report 2007 [Online]. Dublin: The Economic and Social Research Institute \& Department of 
Page 33 of 34

Title: Who knows what are school leavers and graduates doing? Comparing research programmes within Europe

Date of submission: 06/07/2013

Date of resubmission: 13/12/2013

Education and Science. Available:

http://www.education.ie/servlet/blobservlet/stat_school_leaver_survey_2007.pdf [Accessed 26/10/2011].

CAMMELLI, A. 2012. 14th AlmaLaurea Report on Gradutes' Employment Conditions. Young people cannot wait any longer: Investments are needed in education, research, innovation, and culture [Online]. Bologna: Interuniversity Consortium ALMALAUREA. Available:

https://www.almalaurea.it/sites/almalaurea.it/files/docs/universita/occupazione/o ccupazione10/sintesi_en.pdf [Accessed 18/01/2013].

CAREERS WALES. 2012. Destinations - all Wales 2003-2011 [Online]. Gyrfa Cymru Careers Wales. Available: http://www.CAREER

SWALES.com/prof/server.php?show=nav.3845 [Accessed 29/11/2012].

CÉREQ. 2008. Quand l'école est fi nie... Premiers pas dans la vie active de la

Génération 2004 (When school is over... First steps in the working lives of Generation 2004) Available: http://www.cereq.fr/pdf/qeesf2004.pdf [Accessed 26/10/2011].

CÉREQ. 2010. Transition to Work and Occupational Trajectories (DEEVA) [Online]. Marseille: Centre D’Études Et De Recherches Sur Les Qualifications. Available: http://www.cereq.fr/index.php/sous-themes/Transition-to-Work-andOccupational-Trajectories-DEEVA [Accessed 26/10/2011].

CÉREQ. 2011. Présentation des premiers résultats de l'enquête Génération. 2007-2010

- Premiers pas dans la vie active: Le diplôme : un atout gagnant pour les jeunes face à la crise [Online]. Paris: Enquête Génération du Céreq. Available: www.cereq.fr/index.php/content/download/2241/24100/file/dossierdepressegene 2007-4.pdf [Accessed 23/01/2013].

COHN, E. 1979. The economics of education, Cambridge, Mass., Ballinger

COLLINGWOOD, A., CHESHIRE, H., NICOLAAS, G., D’SOUZA, J., ROSS, A., HALL, J., ARMSTRONG, C., PROSSER, A., GREEN, R., COLLINS, D., GRAY, M. \& MCNAUGHTON NICHOLLS, C. 2010. A Review of the Longitudinal Study of Young People in England (LSYPE): Recommendations for a Second Cohort [Online]. NatCen. Available:

https://www.education.gov.uk/publications/eOrderingDownload/DFERR048.pdf [Accessed 21/05/2012].

COUNCIL. 2001. Report from the Education Council to the European Council - "The concrete future objectives of education and training systems" [Online]. Brussels: The Council of the European Union. Available: http://ec.europa.eu/education/lifelong-learning-policy/doc/future_en.pdf [Accessed 05/03/2013].

COUNCIL. 2002. Detailed work programme on the follow-up of the objectives of Education and training systems in Europe (2002/C 142/01) [Online]. Brussels: Official Journal of the European Communities. Available: http://eurlex.europa.eu/LexUriServ/LexUriServ.do?uri=OJ:C:2002:142:0001:0022:EN:P DF [Accessed 05/03/2013].

DALE, R. \& ROBERTSON, S. (eds.) 2009. Globalisation and Europeanisation in Education, Oxford: Symposium Books.

DE VAUS, D. 2001. Research Design in Social Research, London, Sage.

DENI. 2010. School leavers survey [Online]. Bangor: Statistcs and Research Branch, Department of Education. Available: http://www.deni.gov.uk/index/32- 
Page 34 of 34

Title: Who knows what are school leavers and graduates doing? Comparing research programmes within Europe

Date of submission: 06/07/2013

Date of resubmission: 13/12/2013

statisticsandresearch_pg/32-

statistics_and_research_statistics_on_education_pg/32_statistics_on_educationschool_leavers_pg.htm [Accessed 26/10/2011].

DFE. 2011. LSYPE User Guide to the Datasets: Wave 1 to Wave 7 [Online]. Essex:

Economic and Social Data Service. Available:

http://www.esds.ac.uk/doc/5545\%5Cmrdoc\%5Cpdf\%5C5545lsype_user_guide_ wave_1_to_wave_7.pdf [Accessed 01/10/2012].

ESDS. 2008. SN 6024 -Youth Cohort Study: England, Cohort Thirteen, Sweep One to Three, 2007-2009 [Online]. Essex: Economic and Social Data Service.

Available: http://www.esds.ac.uk/findingData/snDescription.asp?sn=6024 [Accessed 26/10/2011].

ESDS. 2009. Youth Cohort Study (YCS), Cohort 13, Sweeps 1 to 3. Quick Start User

Guide [Online]. Essex: ESDS. Available:

http://www.esds.ac.uk/doc/6024\%5Cmrdoc\%5Cpdf\%5C6024ycs_13_s1_s2_s3_ s4_quick_start_user_guide.pdf [Accessed 26/10/2011].

ESDS. 2011. An ESDS guide: Guide to Longitudinal Study of Young People in England [Online]. Essex: ESDS. Available:

http://www.esds.ac.uk/longitudinal/access/lsype/L5545.asp [Accessed 21/01/2013].

ESDS. 2012. SN 5545 -Longitudinal Study of Young People in England: Waves One to Seven, 2004-2010 [Online]. Essex: Economic and Social Data Service.

Available: http://www.esds.ac.uk/findingData/snDescription.asp?sn=5545

[Accessed 26/10/2011].

EU. 2009. Council conclusions of 12 May 2009 on a strategic framework for European cooperation in education and training ('ET 2020') (2009/C 119/02). Available: http://eur-

lex.europa.eu/LexUriServ/LexUriServ.do?uri=OJ:C:2009:119:0002:0010:EN:P DF [Accessed 26/10/2011].

FIELD, J. 2002. Governing the ungovernable - Why lifelong learning policies promise so much yet deliver so little In: EDWARDS, R., MILLER, N., SMALL, N. \& TAIT, A. (eds.) Supporting lifelong learning. Vol.3, Making policy work London: RoutledgeFalmer.

GAEBEL, M., HAUSCHILDT, K., MÜHLECK, K. \& SMIDT, H. 2012. Tracking Learners' and Graduates' Progression Paths (TRACKIT) [Online]. Belgium: European University Association. Available: http://www.eua.be/trackit [Accessed 11/01/2013].

GANGL, M., MÜLLER, W. \& RAFFE, D. 2003. Conclusions: explaining crossnational differences in school-to-work transitions. In: MÜLLER, W. \& GANGL, M. (eds.) Transitions from education to work in Europe. Oxford: Oxford University Press.

GARCÍA-MONTALVO, J. \& MARÍA PEIRÓ, J. 2011. Crisis Economica E Insercion Laboral De Los Jovenes: Resultados del Observatorio de Inserción Laboral de los Jóvenes 2011 [Online]. Valencia: Observatorio de Inserción Laboral de los Jóvenes. Bancaja-Ivie. Available: http://www.ivie.es/downloads/docs/mono/mono2012-01.pdf [Accessed].

GORARD, S. 2009. The potential lifelong learning impact of schooling. In: JARVIS, P. (ed.) The Routledge international handbook of lifelong learning. London: Routledge. 
Page 35 of 34

Title: Who knows what are school leavers and graduates doing? Comparing research programmes within Europe

Date of submission: 06/07/2013

Date of resubmission: 13/12/2013

GORARD, S. 2013. Research Design. Creating Robust Approaches for the Social Sciences London, SAGE.

GRANT, N. 2000. Tasks for Comparative Education in the New Millennium. Comparative Education, 36, 309-317.

HALÁSZ, G. 2012. Az oktatas az Europai Unioban - Tanulas es egyuttmukodes (Education in the European Union - Learning and cooperation), Budapest, $\mathrm{Uj}$ Mandatum Konyvkiado.

HAKIM, C. 2000. Research Design: Successful designs for social and economic research, London, Routledge.

HANNAN F., D., RAFFE, D., SMYTH, E. \& MCCOY, S. 1999. A Comparative Analysis of Transitions from Education to Work in Europe (CATEWE), Volume 1: A Conceptual Framework [Online]. Dublin: The Economic and Social Research Institute. Available:

http://www.esri.ie/UserFiles/publications/20071115105551/WP118a.pdf [Accessed 21/01/2013].

HEA. 2010. What do graduates do? The Class Of 2008 [Online]. Dublin: Higher Education Authority. Available: http://www.hea.ie/files/files/file/statistics/48078\%20HEA\%20graduates\%20rep ort\%2008.pdf [Accessed 15/01/2013].

HESA. 2007. C07018 DLHE Methodology [Online]. Higher Education Statistics Agency. Available: http://www.hesa.ac.uk/index.php?option=com_content\&task=view\&id=1139\&It emid=233 [Accessed 28/11/2012].

HOWIESON, C. \& CROXFORD, L. 2008. Meeting the Needs for Longitudinal Data on Youth Transitions in Scotland - An Options Appraisal. Available: http://www.scotland.gov.uk/Resource/Doc/241671/0067161.pdf [Accessed 26/10/2011].

ISSDA. 2007. School Leavers Survey [Online]. Dublin Irish Social Science Data Archive. Available: http://www.ucd.ie/issda/data/esri/schoolleaverssurvey/ [Accessed 26/10/2011].

ISTAT. 2011. NOTA METODOLOGICA - L'Indagine sui percorsi di studio e di lavoro dei diplomati delle scuole secondarie di secondo grado [Online]. Roma: Istituto nazionale di statistica. Available:

http://www.istat.it/it/files/2011/02/nota_metodologica_diplomati.pdf [Accessed $11 / 02 / 2013]$.

ISTAT. 2012a. NOTA METODOLOGICA - I laureati e il lavoro [Online]. Roma: Istituto nazionale di statistica. Available: http://www.istat.it/it/files/2012/06/Nota_metodologica_stat_report_laureati.pdf?t itle=I+laureati+e+il+lavoro+-+08\%2Fgiu \%2F2012+-+Nota+metodologica.pdf [Accessed 11/02/2013].

ISTAT, 2012b. Graduates and Work - 2011 survey on 2007 graduates. [Online]. Roma: Istituto nazionale di statistica. Available: http://www.istat.it/en/files/2012/09/SintesilEnglish.pdf?title=Graduates+and+w ork+2011++-+21+Sep+2012+-+Full+text.pdf [Accessed: 11/02/2013]

JENSEN, T. H. 2012. Graduate employment (Nyuddannedes beskaftigelse) [Online]. København Styrelsen for Universiteter og Internationalisering. Available: http://www.ubst.dk/uddannelse-og-forskning/statistik/nyuddannedesbeskeftigelse [Accessed 16/01/2013]. 
Page 36 of 34

Title: Who knows what are school leavers and graduates doing? Comparing research programmes within Europe

Date of submission: 06/07/2013

Date of resubmission: 13/12/2013

KULEUVEN. 2011. Studie van de overgang van ONderwijs naar ARbeidsmarkt (SONAR) [Online]. Leuven: Studie- en schoolloopbanen. Available: http://www.steunpuntloopbanen.be/vorm1.html [Accessed 23/01/2013].

LANGE, B. \& ALEXIADOU, N. 2007. New Forms of European Union Governance in the Education Sector? A Preliminary Analysis of the Open Method of Coordination. European Educational Research Journal, 6, 321-335.

LAWN, M. \& GREK, S. 2012. Europeanizing Education: governing a new policy space, Oxford, Symposium Books.

LEMAIRE, S. 2010. Les bacheliers 2008 - Où en sont-ils à la rentrée 2009 ? [Online]. Paris: Note d'Information Enseignement supérieur \& Recherche. Available: http://media.enseignementsuprecherche.gouv.fr/file/2011/57/3/NIMESR1108_176573.pdf [Accessed 15/01/2013].

MACIONIS, J. J. \& PLUMMER, K. 2008. Sociology : a global introduction, Harlow, Pearson Prentice Hall

MAINGUET, C. 1999. The Transition from the Educational System to Working Life. Use of National Statistics [Online]. Thessaloniki: CEDEFOP - European Centre for the Development of Vocational Training. Available: http://www.cedefop.europa.eu/EN/Files/6002_en.pdf [Accessed 11/12/2013]

MCMAHON, W. W. 2004. The social and external benefits of education. In: JOHNES, G. \& JOHNES, G. (eds.) International Handbook on the Economics of Education. Cheltenham: Edward Elgar.

MICHELIS, A. D. \& CHANTRAINE, A. 2003. Memoirs of Eurostat. Fifty years serving Europe [Online]. Luxembourg: Office for Official Publications of the European Communities. Available: http://epp.eurostat.ec.europa.eu/cache/ITY_OFFPUB/KS-49-02-183/EN/KS-4902-183-EN.PDF [Accessed 24/01/2013].

MINCER, J. 1974. Schooling, Experience and Earnings New York, National Bureau of Economic Research.

MÜLLER, W. \& GANGL, M. 2003. The transition from school to work: a European perspective. In: MÜLLER, W. \& GANGL, M. (eds.) Transitions from education to work in Europe. The integration of youth into EU labour markets. Oxford: Oxford University Press.

MYRSKYLÄ, P. 2001. The Use of Administrative Register Data for Longitudinal Studies - Transition of Attainers of Educational Qualifications to Working Life [Online]. Seoul Available: http://isi.cbs.nl/iamamember/CD2/pdf/366.PDF [Accessed 26/10/2011].

NEWBY, P. 2010. Research methods for education, Harlow, Pearson Education Limited.

OKM. 2007. Diplomások Pályakövetési Rendszere intézményi kézikönyv [Online]. Budapest: Oktatási és Kulturális Minisztérium. Available: http://www.nefmi.gov.hu/letolt/ds/diplomasok_palyakovetesi_rendszere_071108 .pdf [Accessed].

OUANE, A. 2009. UNESCO's drive for lifelong learning. In: JARVIS, P. (ed.) The Routledge international handbook of lifelong learning. London: Routledge.

PHILLIPS, D. \& SCHWEISFURTH, M. 2006. Comparative and international education : an introduction to theory, method and practice, London, Continuum.

PLOYHART, R. \& VANDENBERG, R. 2010. Longitudinal Research: The Theory, 
Title: Who knows what are school leavers and graduates doing? Comparing research programmes within Europe

Date of submission: 06/07/2013

Date of resubmission: 13/12/2013

Design, and Analysis of Change. Journal of Management, 36, 94-119.

PSACHAROPOULOS, G. \& PATRINOS, H. A. 2004. Human capital and rates of return In: JOHNES, G. \& JOHNES, J. (eds.) International Handbook on the Economics of Education. Cheltenham: Edward Elgar.

PUHAKKA, A. \& TUOMINEN, V. 2011. As long as it takes five years - Master's degree graduates careers (Kunhan kuluu viisi vuotta - ylemmän korkeakoulututkinnon suorittaneiden työurat) [Online]. Tampere: Aarresaariverkosto. [Accessed].

RAFFE, D. 2008. The concept of transition system. Journal of Education and Work, 21, 277-296.

RAGIN, C. C. 1987. The comparative method: moving beyond qualitative and quantitative strategies London, University of California Press.

REHN, T., BRANDT, G., FABIAN, G. \& BRIEDIS, K. 2011. Hochschulabschlüsse im Umbruch: Studium und Übergang von Absolventinnen und Absolventen reformierter und traditioneller Studiengänge des Jahrgangs 2009 [Online]. Hannover: HIS Hochschul-Informations-System GmbH. Available: http://www.his.de/pdf/pub_fh/fh-201117.pdf [Accessed 15/01/2013].

ROA. 2009. School-leaver surveys [Online]. Maastricht: Maastricht University. Available: http://www.roa.unimaas.nl/nw_school_leaver_survey.htm [Accessed 26/10/2011].

RUSPINI, E. 2000. Longitudinal Research in the Social Sciences [Online]. Guildford: Department of Sociology, University of Surrey. Available: http://sru.soc.surrey.ac.uk/SRU28.html [Accessed 26/10/2011].

RUSPINI, E. 2002. Introduction to longitudinal research, London; New York, Routledge.

SAINO, J. 2010. Tracking systems in Finnish universities. Turku.

SAMUELSSON, D. 2004. Inträdet på arbetsmarknaden (The entrance to the Labour market) [Online]. Stockholm Statistics Sweden. Available: http://www.scb.se/statistik/UF/UF0512/2004A01/UF0512_2004A01_SM_UF86 SM0401.pdf [Accessed 22/01/2013].

SCHULLER, T. 2009. The OECD and lifelong learning. In: JARVIS, P. (ed.) The Routledge international handbook of lifelong learning. London: Routledge.

SCOTSTAT. 2009. Follow up survey of leavers from Scottish schools: leavers from school year 2007/08 [Online]. Edinburgh: Scottish Government Education Directorate. Available: http://www.scotland.gov.uk/Resource/Doc/1038/0083381.pdf [Accessed 26/10/2011].

SCOTSTAT. 2010. Destinations of Leavers from Scottish Schools: 2009/10 [Online]. Edinburgh: Scottish Government Education Directorate. Available: http://www.scotland.gov.uk/Resource/Doc/332876/0108399.pdf [Accessed 26/10/2011].

SFC. 2010. On Track: Class of 2004. Report on fourth and final sweep [Online]. Edinburgh: Ipsos MORI Scotland; Scottish Funding Councils for Further and Higher Education. Available:

http://www.sfc.ac.uk/web/FILES/ReportsandPublications/On_Track_Class_of_2 004_fourth_and_final_sweep.pdf [Accessed 18/01/2013].

SMITH, E. 2008. Using secondary data in educational and social research, Maidenhead McGraw-Hill Open University Press. 
Title: Who knows what are school leavers and graduates doing? Comparing research programmes within Europe

Date of submission: 06/07/2013

Date of resubmission: 13/12/2013

SMYTH, E., GANGL, M., RAFFE, D., HANNAN F., D. \& MCCOY, S. 2001. A Comparative Analysis of Transitions from Education to Work in Europe (CATEWE). Available: http://www.mzes.unimannheim.de/projekte/catewe/publ/publ_e.html [Accessed 26/10/2011].

STANDING, G. 1997 Labour Market Governance in Eastern Europe. European Journal of Industrial Relations, 3: 133-159

STATISTICS AUSTRIA. 2012. Education-related employment career monitoring [Online]. Vienna: Statistics Austria. Available: http://www.statistik.at/web_en/statistics/education_culture/monitoring_educatio n_related_employment_behaviour/index.html [Accessed 16/01/2013].

STATISTICS DENMARK. 2012. From education to labour market (Fra uddannelse til arbejdsmarked) [Online]. København: Statistics Denmark. Available: http://www.dst.dk/da/Statistik/emner/uddannelsesforloeb/fra-uddannelse-tilarbejdsmarked.aspx?tab=nog [Accessed 16/01/2013].

STATISTICS FINLAND. 2011. Description of statistics: Transition from school to further education and work [Online]. Helsinki: Statistics Finland. Available: http://www.stat.fi/meta/til/sijk_en.html [Accessed 26/10/2011].

STATISTICS FINLAND. 2012. Transition from school to further education and work [Online]. Helsinki: Statistics Finland. Available: http://www.stat.fi/til/sijk/index_en.html [Accessed 20/12/2012].

STATISTICS SWEDEN. 2012. The transition from upper secondary school to higher education, School year 2010/11: Natural science pupils most likely to continue with higher education [Online]. Stockholm: Statistics Sweden. Available: http://www.scb.se/Pages/PressRelease__339980.aspx [Accessed 18/01/2013].

UNI BAMBERG, 2010a. The National Educational Panel Study website [Online]. Bamberg: National Educational Panel Study, University of Bamberg. Available: https://www.neps-data.de [Accessed 11/02/2013].

UNI BAMBERG. 2010b. The National Educational Panel Study - Need, Main Features, and Research Potential [Online]. Bamberg: National Educational Panel Study, University of Bamberg. Available: https://www.nepsdata.de/Portals/0/Neps/NEPS_Brochure_english.pdf [Accessed 18/01/2013].

UNITED NATIONS 2007. Register-based statistics in the Nordic countries. Review of best practices with focus on population and social statistics, Geneva, United Nations Publications.

VON MAURICE, J., SIXT, M \& BLOSSFELD, H-P. 2011. The German National Educational Panel Study: Surveying a Cohort of $9^{\text {th }}$ Graders in Germany. NEPS Working Paper No. 3. [Online]. Bamberg: National Educational Panel Study, University of Bamberg. Available: https://www.nepsdata.de/Portals/0/Working\%20Papers/WP_III.pdf [Accessed 11/02/2013]

VSNU. 2007. Research Universities in the Netherlands - The association of universities in The Netherlands represents all of the country's research universities [Online]. The Hague: VSNU. Available: http://www.vsnu.nl/web/file?uuid=ee40c84f44d1-4063-b135-4f6a0f5a2948\&owner=30689d27-c794-4a77-a4b199268909879a\&contentid=383 [Accessed 15/05/2012]. 
Page 39 of 34

Title: Who knows what are school leavers and graduates doing? Comparing research programmes within Europe

Date of submission: 06/07/2013

Date of resubmission: 13/12/2013 